\title{
Rosehip inhibits xanthine oxidase activity and reduces serum urate levels in a mouse model of hyperuricemia
}

\author{
HIDETOMO KIKUCHI $^{1 *}$, SATOMI KOGURE ${ }^{1 *}$, RIE ARAI $^{1}$, KOUKI SAINO $^{1}$, \\ ATSUKO OHKUBO $^{2}$, TADASHI TSUDA ${ }^{1}$ and KATSUYOSHI SUNAGA ${ }^{1}$ \\ ${ }^{1}$ Department of Clinical Dietetics and Human Nutrition, Faculty of Pharmaceutical Sciences, Josai University, \\ Sakado, Saitama 350-0295; ${ }^{2}$ Development Division, Ryusendo Co., Ltd., Toshimaku, Tokyo 171-0021, Japan
}

Received February 16, 2017; Accepted March 23, 2017

DOI: $10.3892 / \mathrm{br} .2017 .888$

\begin{abstract}
Rosehip, the fruit of Rosa canina L., has traditionally been used to treat urate metabolism disorders; however, its effects on such disorders have not been characterized in detail. Therefore, the present study investigated the effects of hot water, ethanol and ethyl acetate extracts of rosehip on xanthine oxidase (XO) activity in vitro. In addition, the serum urate lowering effects of the rosehip hot water extract in a mouse model of hyperuricemia (male ddY mice, which were intraperitoneally injected with potassium oxonate) were investigated. Furthermore, the influence of rosehip hot water extract on CYP3A4 activity, which is the most important drug-metabolizing enzyme from a herb-drug interaction perspective, was investigated. Rosehip extracts of hot water, ethanol and ethyl acetate inhibited XO activity [half maximal inhibitory concentration $\left(\mathrm{IC}_{50}\right.$ ) values: $259.6 \pm 50.6,242.5 \pm 46.2$ and $1,462.8 \pm 544.2 \mu \mathrm{g} / \mathrm{ml}$, respectively]. Furthermore, the administration of $1 \mathrm{X}$ rosehip hot water extract significantly reduced the levels of serum urate at $8 \mathrm{~h}$, which was similar when compared with the administration of $1 \mathrm{mg} / \mathrm{kg}$ allopurinol. Rosehip hot water extract only marginally affected CYP3A4 activity $\left(\mathrm{IC}_{50}\right.$ value, $\left.>1 \mathrm{mg} / \mathrm{ml}\right)$. These findings indicate that rosehip hot water extract may present as a functional food for
\end{abstract}

Correspondence to: Dr Katsuyoshi Sunaga, Department of Clinical Dietetics and Human Nutrition, Faculty of Pharmaceutical Sciences, Josai University, 1-1 Keyakidai, Sakado, Saitama 350-0295, Japan

E-mail: ksunaga@josai.ac.jp

${ }^{*}$ Contributed equally

Abbreviations: CYP, cytochrome $\mathrm{P} 450$; XO, xanthine oxidase; $\beta$-NADP ${ }^{+}$, nicotinamide adenine dinucleotide phosphate oxidized form; G-6-P, glucose-6-phosphate; G-6-PDH, glucose-6-phosphate dehydrogenase; DMSO, dimethyl sulfoxide; ODS, octadecylsilyl; Tris, 2-amino-2-hydroxymethyl-1,3-propanediol; PO, potassium oxonate

Key words: rosehip extract, xanthine oxidase activity, CYP3A4 activity, hyperuricemic mice, functional foods, self-medication individuals with a high urate level, and as a therapeutic reagent for hyperuricemic patients.

\section{Introduction}

Certain types of food exert beneficial effects on human health; however, the effects are not explained by the nutritional content, such as macronutrients, vitamins and minerals (1). These types of food, termed functional foods, are food-derived products that enhance normal physiological or cognitive functions, or prevent the abnormal function that underlies disease (1). These food types also contribute to the promotion of self-medication, i.e., the use of over-the-counter medicines, including herbal and traditional products, to treat self-recognized illnesses or symptoms $(1,2)$. Of particular interest is the biological activity and safety of natural products, including food, traditional herbs, kampo and their phytochemicals (3-13).

Rosehip is the fruit of rose plants within the genus Rosa, in particular Rosa canina L., also termed dog rose. Rosehip has a particularly high vitamin $\mathrm{C}$ content compared with other fruits and vegetables $(14,15)$, and contains other vitamins, minerals, sugars, fatty acids and flavonoids (14). Rosehip has traditionally been administered for the treatment of colds, infectious diseases and inflammatory diseases (16). In support of its traditional uses, various studies have reported that rosehip exhibited bioactivity, including antioxidant (17,18), anti-inflammatory (19-22), hepatoprotective (23), anti-diabetic (17) and anti-obesity (24) effects. Therefore, rosehip may be considered a functional food that promotes health. Although rosehip has traditionally been administered for treating uric acid (urate) metabolism disorders (16), its effects have not been characterized in detail.

In humans, urate is the end product of purine metabolism and is delivered from hypoxanthine following double enzyme catalysis by xanthine oxidase (XO) in the liver (25). Serum urate production is regulated by the endogenous (de novo purine synthesis and tissue catabolism under normal circumstances) and exogenous (diet including animal protein) precursor proteins delivered to the liver; whereas its excretion is controlled by the kidneys through renal plasma flow, glomerular filtration and proximal tubular exchange $(26,27)$. The imbalance of its production and excretion induces hyperuricemia, which also develops into gout and kidney stones, and accelerates the progression of renal and cardiovascular 
diseases $(28,29)$. Potassium oxonate $(\mathrm{PO})$-treated mice generally serve as a model of urate overproduction (hyperuricemia), as its intraperitoneal injection induces the overproduction of urate in mice (30-33). Indeed, a previous study using PO-treated ABCG2-knockout mice reported that a decrease of extra-renal urate excretion was one of the most common causes of hyperuricemia (33).

Numerous studies have demonstrated that the simultaneous administration of a food or beverage that inhibits drug-metabolizing enzymes, such as cytochrome P450 (CYP), and a drug that is metabolized by said enzyme alters blood concentrations, although occasionally with adverse effects (34). A phenomenon similar to this food-drug interaction can be generated between food and drugs. Indeed, it has previously been demonstrated that beverages and food, such as beer, red wine, black and herbal tea, garlic, spices, mace, nutmeg, fruit and fruit juice, tomato juice, and licorice root inhibited enzyme-mediated drug metabolism (9,10,35-39). Although rosehip has been used as a food and as a traditional medicine (16), to the best of our knowledge, there is no evidence of an interaction between rosehip and CYP3A4-metabolizing drugs.

In the present study, the effects of hot water, ethanol and ethyl acetate extracts of rosehip on $\mathrm{XO}$ activity were investigated in an in vitro assay. In addition, the effect of rosehip hot water extract on urate metabolism was evaluated according to the level of serum urate in hyperuricemia model mice. Furthermore, whether rosehip hot water extract inhibits CYP3A4 activity in vitro was investigated.

\section{Materials and methods}

Materials. Unless otherwise stated, the various reagents and the Urate C-test Wako kit were purchased from Wako Pure Chemical Industries, Ltd. (Osaka, Japan). Rosehip was obtained from the Tree of Life Co. (Tokyo, Japan). Xanthine oxidase (from buttermilk), nicotinamide adenine dinucleotide phosphate oxidized form $\left(\beta-\mathrm{NADP}^{+}\right)$, glucose- 6 -phosphate (G-6-P), and G-6-P dehydrogenase (G-6-PDH) were purchased from Oriental Yeast, Ltd. (Tokyo, Japan). Dimethyl sulfoxide (DMSO) and 11 $\alpha$-hydroxyprogesterone were purchased from Sigma-Aldrich (Merck KGaA, Darmstadt, Germany). Human CYP3A4R Bactosomes (recombinant CYP3A4) were purchased from Cypex Ltd. (Scotland, UK). Mightysil RP-18 GP 250-4.6 (5 $\mu \mathrm{m})$ [Octadecylsilyl (ODS) column] was purchased from Kanto Chemical, Co., Inc. (Tokyo, Japan).

Preparation of rosehip hot water extract. The extract was prepared from triturated powder $(1 \mathrm{~g})$ with $20 \mathrm{ml}$ MilliQ-water at room temperature and decocted at $100^{\circ} \mathrm{C}$ for $30 \mathrm{~min}$. The extract was cooled, filtered and evaporated using a freeze dryer, after which the dried sample (yield, $65.2 \%$ ) was weighed and dissolved at a concentration of $50 \mathrm{mg} / \mathrm{ml}$ in MilliQ-water.

Preparation of rosehip ethanol or ethyl acetate extracts. The extracts were prepared from triturated powder $(1 \mathrm{~g})$ with $20 \mathrm{ml}$ ethanol or ethyl acetate and agitated at room temperature for $2 \mathrm{~h}$. The extracts, with ethanol or ethyl acetate, were subsequently filtered and evaporated, after which the dried samples were weighed (yields, 5.66 and $0.85 \%$, respectively) and prepared at a concentration of 50 or $100 \mathrm{mg} / \mathrm{ml}$ in DMSO, respectively.

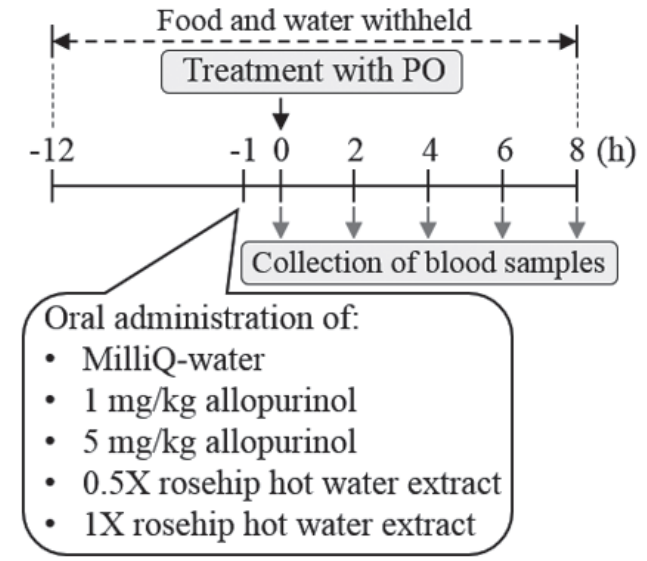

Figure 1. Diagram of the timeline of treatment with rosehip hot water extracts and allopurinol in the hyperuricemia model mice.

Measurement of XO activity in vitro. The measurement of XO activity was performed in accordance with previously published methods with modifications (40). Briefly, $151.5 \mu 1$ Tris- $\mathrm{HCl}$ buffer (pH 7.5; $100 \mathrm{mM}), 7.5 \mu \mathrm{l} \mathrm{XO}(0.4 \mathrm{U} / \mathrm{m})$ in $50 \mathrm{mM}$ Tris- $\mathrm{HCl}$ buffer ( $\mathrm{pH} 7.5$ ), and $9 \mu 1$ rosehip extracts [concentrations, 10, 20, 50 and $100 \mathrm{mg} / \mathrm{ml}$ (final concentrations, 500, 1,000, 2,500 and $5,000 \mu \mathrm{g} / \mathrm{ml}$, respectively) in the ethyl acetate extract, and 0.5 , $1,5,10,50 \mathrm{mg} / \mathrm{ml}$ (final concentrations, 25, 50, 250, 500 and $2,500 \mu \mathrm{g} / \mathrm{ml}$, respectively) in the hot water and ethanol extracts] were mixed in $1.5-\mathrm{ml}$ tubes. These tubes were pre-incubated in a heat-block at $37^{\circ} \mathrm{C}$ for $5 \mathrm{~min}$. Subsequently, $12 \mu \mathrm{l}$ xanthine $(80 \mu \mathrm{M})$ in $25 \mathrm{mM} \mathrm{NaOH}$ was added and incubated at $37^{\circ} \mathrm{C}$ for $30 \mathrm{~min}$. The tubes were incubated at $100^{\circ} \mathrm{C}$ for $1 \mathrm{~min}$ to terminate the reaction. To measure the quantities of urate production, the Urate $\mathrm{C}$-test Wako kit was used according to the manufacturer's protocol. The relative XO activity was expressed as a ratio of the absorbance of each rosehip extract group to that of the corresponding vehicle control group (MilliQ-water or DMSO). The half maximal inhibitory concentration $\left(\mathrm{IC}_{50}\right)$ values were calculated from the $\mathrm{XO}$ activity curves.

Animals. All experiments and the care and handling of the animals were approved by Josai University (Sakado, Japan) Institutional Animal Care and Use Committee. Thirty male ddY mice (age, 5 weeks), obtained from Sankyo Labo Service Corporation, Inc. (Tokyo, Japan) were used. The mice were housed in six cages with five mice per cage. They were exposed to a 12-h light/dark cycle and maintained at a constant temperature of $22 \pm 2^{\circ} \mathrm{C}$ and humidity of $55 \pm 10 \%$. The mice were allowed 1 week to adapt to the laboratory environment prior to the experiments and fed laboratory pellet chow (CE-2; CLEA Japan Inc., Tokyo, Japan) and water ad libitum. All mice were euthanized by the intraperitoneal injection of pentobarbital sodium following completion of the experiments.

Treatment of hyperuricemia model mice with rosehip hot water extracts and allopurinol PO, a uricase inhibitor, was used to establish the hyperuricemia model mice, as described previously (30-33). Briefly, pellet chow and water supplies to the ddY mice (age, 6 weeks; body weight, $31.0 \pm 0.37 \mathrm{~g}$ ) were halted the night before the experiment. The mice were randomly divided into five groups ( $\mathrm{n}=7$ in the control group; $\mathrm{n}=5$ in the $5 \mathrm{mg} / \mathrm{ml}$ allopurinol group; and $\mathrm{n}=6$ in the $1 \mathrm{mg} / \mathrm{ml}$ allopurinol, $0.5 \mathrm{X}$ 
A

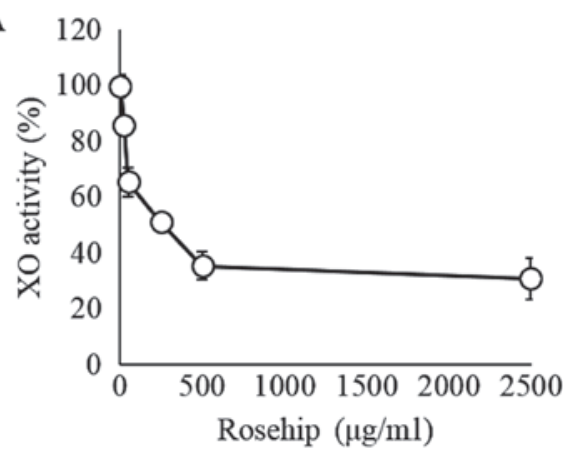

B

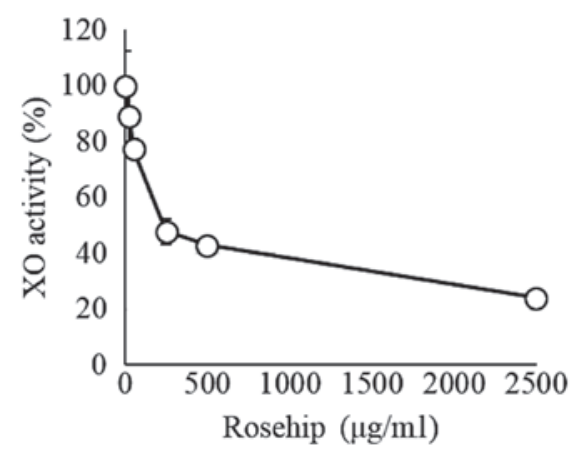

C

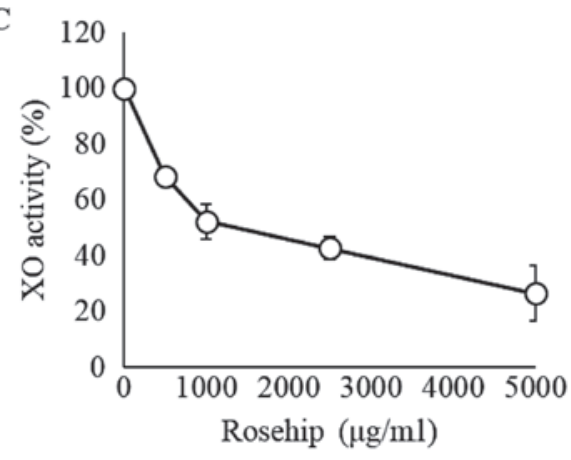

D

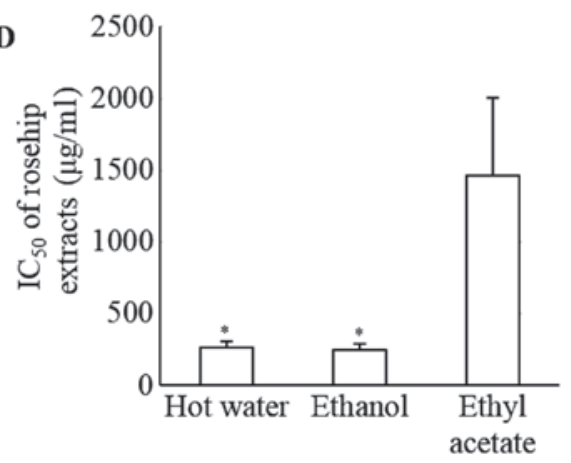

Figure 2. Effect of rosehip extracts on XO activity. (A) Hot water extract, (B) ethanol extract, and (C) ethyl acetate extract of rosehip dose-dependently reduced $\mathrm{XO}$ activity. (D) The $\mathrm{IC}_{50}$ values of each extract were calculated and compared. Data are reported as means \pm standard deviation. "P $<0.05$ vs. ethyl acetate extraction. XO, xanthine oxidase; $\mathrm{IC}_{50}$, half maximal inhibitory concentration.

or $1 \mathrm{X}$ rosehip hot water extract groups. The mice were treated with $\mathrm{PO}$ in $0.5 \% \mathrm{CMC}-\mathrm{Na}(280 \mathrm{mg} / \mathrm{kg}$, i.p.) $1 \mathrm{~h}$ before oral administration of $5 \mathrm{ml} / \mathrm{kg}$ MilliQ-water (as the control group), 1 or $5 \mathrm{mg} / \mathrm{kg}$ allopurinol, or $5 \mathrm{ml} / \mathrm{kg}$ of $0.5 \mathrm{X}$ or $1 \mathrm{X}$ rosehip hot water extract $(\sim 82.5$ and $\sim 165 \mathrm{mg} / \mathrm{kg}$, respectively). A diagram of the timeline of the experiment is presented in Fig. 1.

Measurement of serum urate. Blood samples $(0.1 \mathrm{ml})$ were collected into $0.6-\mathrm{ml}$ tubes sequentially at 2, 4, 6 and $8 \mathrm{~h}$ via a small incision in the tail vein using a razor blade. The blood samples were incubated for $1 \mathrm{~h}$ at room temperature and centrifuged at $800 \times \mathrm{g}$ at $4^{\circ} \mathrm{C}$ for $15 \mathrm{~min}$. The supernatant $(\sim 20 \mu \mathrm{l})$ from each blood sample was collected as serum samples and stored at $-20^{\circ} \mathrm{C}$ until use. The quantity of serum urate in $3.3 \mu \mathrm{l}$ of each serum sample was measured using the Urate C-test Wako kit, according to the manufacturer's protocol.

Measurement of CYP3A4 activity in vitro. Measurement of CYP3A4 activity was performed according to a previously described method (10). Briefly, $125 \mu \mathrm{l}$ NADPH regenerating system [2.6 mM $\beta$-NADP, $6.6 \mathrm{mM} \mathrm{G}-6-\mathrm{P}$ and $6.6 \mathrm{mM} \mathrm{MgCl}_{2}$ in $400 \mathrm{mM}$ potassium phosphate buffer $(\mathrm{pH} 7.4)], 12.5 \mu \mathrm{l}$ G-6-PDH (4 U/ml) in 100 mM Tris-HCl buffer (pH 7.4), $2.5 \mu \mathrm{l}$ recombinant CYP3A4 $(1.0 \mathrm{nmol} / \mathrm{ml}), 3.75 \mu \mathrm{l}$ rosehip hot water extracts [concentrations, $0.8,7.4,22.2,44.4$ and $66.7 \mathrm{mg} / \mathrm{ml}$ (final concentrations, 12, 111,333, 666 and 1,000 $\mu \mathrm{g} / \mathrm{ml}$, respectively)], and $105 \mu$ l MilliQ-water were mixed and preincubated at $37^{\circ} \mathrm{C}$ for $10 \mathrm{~min}$. The reaction was initiated by the addition of $1.25 \mu \mathrm{l}$ testosterone $(60 \mathrm{mM})$. The reaction was terminated by the addition of $500 \mu 111 \alpha$-hydroxyprogesterone $(10 \mu \mathrm{M})$ to the ethyl acetate after $15 \mathrm{~min}$. Following centrifugation
(15,000 x g for $5 \mathrm{~min}), 400 \mu \mathrm{l}$ supernatant was collected, dried and suspended in $200 \mu \mathrm{l}$ methanol. Analyses of the metabolite, $6 \beta$-hydroxytestosterone, were performed using a high-performance liquid chromatography (HPLC) system (PU-2089, UV-2075 and AS-2057; JASCO Corp., Tokyo, Japan) equipped with an ODS column. The mobile phase consisted of $70 \%(\mathrm{v} / \mathrm{v})$ methanol and the metabolites were separated at a flow rate of $1.0 \mathrm{ml} / \mathrm{min}$. Quantification of the metabolite was performed by comparing the HPLC peak area at $254 \mathrm{~nm}$ to that of $11 \alpha$-hydroxyprogesterone, the internal standard. The retention times for $6 \beta$-hydroxytestosterone, $11 \alpha$-hydroxyprogesterone and testosterone were $\sim 4.3, \sim 6.2$ and $\sim 8.6$ min, respectively. The relative CYP3A4 activity was expressed as the ratio of the HPLC peak area of each rosehip extract group to that of the corresponding vehicle (MilliQ-water) control group.

Statistical analysis. Statistical analysis was performed using the software BellCurve for Excel Ver. 2.1 (Social Survey Research Information Co., Ltd., Tokyo, Japan). After applying a rejection test, data were analyzed using Student's t-test and $\mathrm{P}<0.05$ was considered to indicate a statistically significant difference. Data are reported as means \pm standard deviation in vitro and as means \pm standard error of the mean in vivo.

\section{Results}

Dose-dependent effects of rosehip extracts on XO activities. To investigate the $\mathrm{XO}$ inhibitory effects of rosehip extracts, the $\mathrm{XO}$ activity was assessed in vitro. Significant decreases in $\mathrm{XO}$ activity were observed in a dose-dependent manner for the hot water, ethanol and ethyl acetate extracts (Fig. 2A-C, 


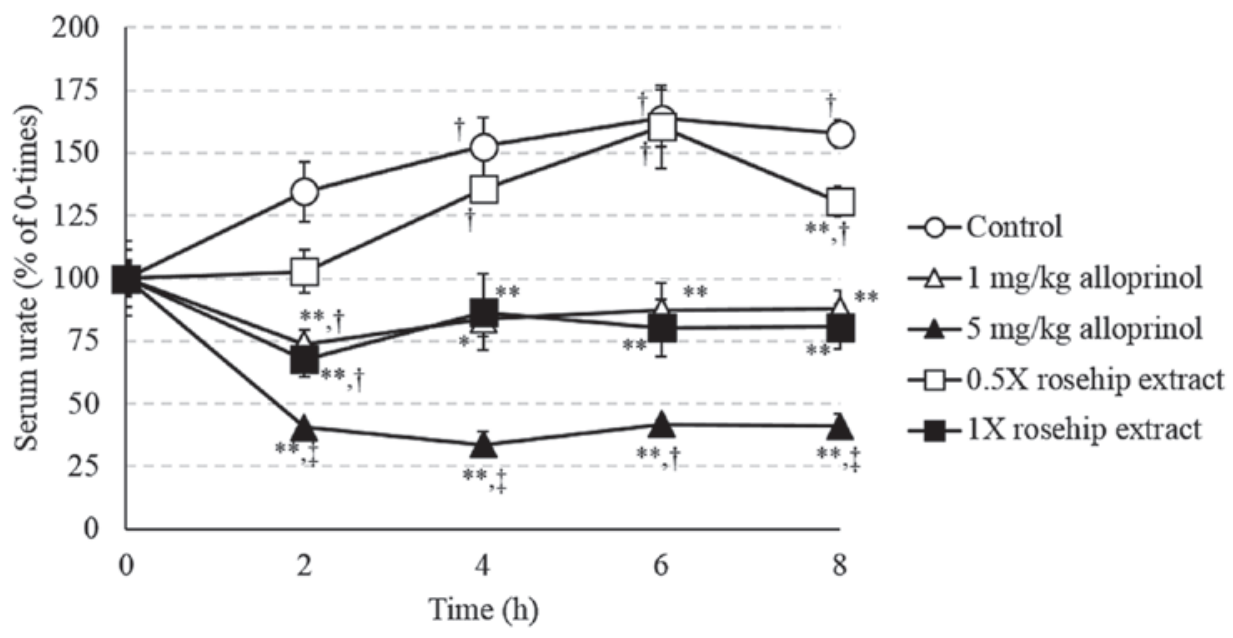

Figure 3. Levels of serum urate in hyperuricemic mice treated with vehicle, $1 \mathrm{mg} / \mathrm{ml}$ allopurinol, $5 \mathrm{mg} / \mathrm{ml}$ allopurinol, $0.5 \mathrm{X}$ rosehip extract, and $1 \mathrm{X}$ rosehip extract. Data are presented as means \pm standard error of the mean. ${ }^{*} \mathrm{P}<0.05$ and ${ }^{* *} \mathrm{P}<0.01$ vs. control group; ${ }^{\dagger} \mathrm{P}<0.05$ and ${ }^{\dagger} \mathrm{P}<0.01$ vs. each case at time 0 .

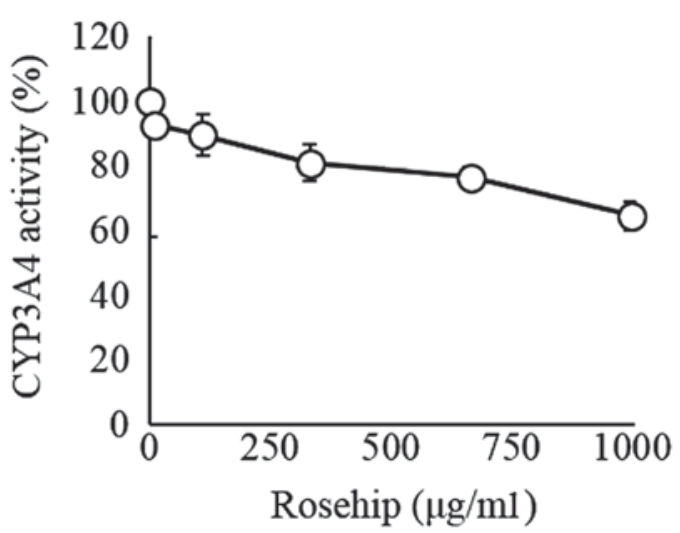

Figure 4. Effect of rosehip extracts on CYP3A4 activity. Data are presented as means \pm standard deviation.

respectively). As shown in Fig. $2 \mathrm{D}$, the $\mathrm{IC}_{50}$ values were $259.6 \pm 50.6,242.5 \pm 46.2$ and $1,462.8 \pm 544.2 \mu \mathrm{g} / \mathrm{ml}$, respectively. These values differed significantly between the ethyl acetate extract, and the hot water or ethanol extract groups $(\mathrm{P}<0.05$; Fig. 2D).

Effects of rosehip hot water extract on serum urate levels in hyperuricemic mice. All mice were healthy prior to the experiment and adverse events were not detected during the experiment itself. Treatment with PO, a uricase inhibitor, caused hyperuricemia in the mice, as indicated by a significant increase in serum urate levels at 4,6 , and $8 \mathrm{~h}(\mathrm{P}<0.05$; Fig. 3). The levels of serum urate upon administration of $5 \mathrm{mg} / \mathrm{kg}$ allopurinol (the $5 \mathrm{mg} / \mathrm{kg}$ allopurinol group) were significantly lower when compared with time $0(\mathrm{P}<0.05$ at $6 \mathrm{~h} ; \mathrm{P}<0.01$ at the other time-points) and compared with the levels in the control groups at each time-point $(\mathrm{P}<0.01)$. The levels of serum urate upon administration of $1 \mathrm{mg} / \mathrm{kg}$ allopurinol (the $1 \mathrm{mg} / \mathrm{kg}$ allopurinol group) and $1 \mathrm{X}$ rosehip hot water extract (1X rosehip extract group) were significantly lower at $2 \mathrm{~h}$ than at time 0 $(\mathrm{P}<0.05)$, however, did not change at 4, 6 and $8 \mathrm{~h}$. Furthermore, these levels were significantly lower than the levels in the control group $(\mathrm{P}<0.01)$, although there was no difference in these levels at each point between the $1 \mathrm{mg} / \mathrm{kg}$ allopurinol group and the $1 \mathrm{X}$ rosehip extract group $(\mathrm{P}>0.05)$. The levels of serum urate upon administration of $0.5 \mathrm{X}$ rosehip hot water extract (the $0.5 \mathrm{X}$ rosehip extract group) were significantly higher at 4,6 and $8 \mathrm{~h}$ than at time $0(\mathrm{P}<0.05)$. Furthermore, these levels were significantly lower when compared with the levels in the control group at $8 \mathrm{~h}(\mathrm{P}<0.01)$.

Effects of rosehip hot water extract on CYP3A4 activities. The addition of rosehip hot water extract tended to decrease the CYP3A4 activity in a dose-dependent manner, although this decrease was not significant (Fig. 4). Furthermore, at the highest examined concentration $(1 \mathrm{mg} / \mathrm{ml})$, rosehip hot water extract inhibited only $40 \%$ of CYP3A4 activity $\left(\mathrm{IC}_{50}\right.$ value, $>1 \mathrm{mg} / \mathrm{ml}$ ).

\section{Discussion}

In the present study, it was demonstrated that each of the rosehip extracts obtained using hot water, ethanol, and ethyl acetate inhibited XO activity. The different methods of extracting rosehip also generated different strengths of inhibitory effect, namely, the hot water and ethanol extracts exhibited markedly stronger dose-dependent inhibition of XO activity when compared with the ethyl acetate extract. Numerous studies have suggested that the particular polarity of an extraction solvent affects the biological activity of the extract $(20,41,42)$; for example, the free radical scavenging activities associated with extracts of Galla chinensis, a traditional Chinese herb, were in the following order: Ethyl acetate (weak polarity) >ether polarity), because an antioxidant phytochemical, tannin, in this extract is soluble in non-polar or weak polar solvents (41). Certain studies have reported that polyphenols, flavonoids and saponins are potent XO inhibitors (43-46), and rosehip contains numerous phenolic phytochemicals (47). Taking these previous results and the observations of the current study into account, the difference in the inhibitory effect of rosehip extracts on $\mathrm{XO}$ activity may be associated with the polarity of the extraction solvent, and rosehip containing phenolic phytochemicals, the principal substances, are more likely to 
induce an inhibitory effect. Identification of the XO-inhibiting constituents in rosehip is currently underway.

The end product of purine metabolism varies between species. In the majority of mammals, urate is converted to allantoin, a more soluble product that is easily excreted in the urine, by the enzyme uricase (also termed urate oxidase). However, uricase was lost in hominoids during primate evolution (25). To mimic the purine metabolism of humans who lack uricase, mice were exposed to PO, a uricase inhibitor (30-33). In the current study, the oral administration of hot water extract was selected in hyperuricemic mice, as rosehip has typically been used for herbal tea and this extract had a high yield when compared with extracts from other extraction methods. In addition, allopurinol, an XO inhibitor, was administered to serve as a positive control. The administration of 1 and $5 \mathrm{mg} / \mathrm{kg}$ allopurinol in hyperuricemic mice significantly and dose-dependently decreased the level of serum urate at each time-point, indicating that each dose of allopurinol effectively inhibited XO activity in the hyperuricemic mice. Furthermore, the administration of $1 \mathrm{X}$ rosehip extract reduced the increased serum urate level to the same extent as the administration of $1 \mathrm{mg} / \mathrm{kg}$ allopurinol. This is identical to the effect observed in the $1 \mathrm{mg} / \mathrm{kg}$ allopurinol group, suggesting that the inhibitory effect of $1 \mathrm{X}$ rosehip hot water extract on $\mathrm{XO}$ activity virtually mimicked the effect of $1 \mathrm{mg} / \mathrm{kg}$ allopurinol.

CYP3A4 is considered to be the most important drug-metabolizing enzyme, as it metabolizes $>50 \%$ of all clinical drugs (48). It is necessary to consider herb-drug interactions in order to use herbs safely $(9,10,35-39)$. The present study attempted to determine whether rosehip hot water extract inhibited CYP3A4 activity. In the current study, although $12-1,000 \mu \mathrm{g} / \mathrm{ml}$ rosehip hot water extract tended to exhibit dose-dependent inhibition of CYP3A4 activity, it had a very weak effect. Therefore, the risk of interaction between rosehip hot water extract and CYP3A4 substrate drugs appears to be low. Furthermore, other studies reported that ethyl acetate, n-butanol and ethanol extracts from rosehip did not induce toxicity in an acute toxicity test in mice (20), and favorable results were obtained from clinical trials in osteoarthritis (49-51). Thus, the safety of rosehip has been confirmed by traditional experiences of its use, as well as by safety testing.

In conclusion, the current study has demonstrated for the first time, to the best of our knowledge, that hot water, ethanol and ethyl acetate extracts of rosehip inhibited XO activity in vitro and that this inhibitory effect was greater for the hot water and ethanol extracts. In addition, the oral administration of rosehip hot water extract decreased the levels of serum urate in hyperuricemic mice, as a result of the inhibition of XO activity. Notably, rosehip hot water extract exerted little effect on CYP3A4 activity. Collectively, these results indicate that rosehip hot water extract is a promising candidate as a functional food for individuals with a high urate level and as a therapeutic reagent of hyperuricemic patients.

\section{Acknowledgements}

The present study was supported by the Japan Medical Herb Association (grant no. FY 2016 for KS). This manuscript was edited for English language, grammar, punctuation and spelling by Enago (Mumbai, India).

\section{References}

1. Galland L: Functional Foods: Health Effects and Clinical Applications. Elsevier Ltd., pp366-371, 2013.

2. World Health Organization (WHO): The role of the pharmacist in self-care and self-medication. WHO, Geneva, p15, 1998.

3. Kikuchi H, Yuan B, Yuhara E, Imai M, Furutani R, Fukushima S, Hazama S, Hirobe C, Ohyama K, Takagi N, et al: Involvement of histone $\mathrm{H} 3$ phosphorylation via the activation of p38 MAPK pathway and intracellular redox status in cytotoxicity of HL-60 cells induced by Vitex agnus-castus fruit extract. Int J Oncol 45: 843-852, 2014

4. Kikuchi H, Yuan B, Yuhara E, Takagi N and Toyoda H: Involvement of histone $\mathrm{H} 3$ phosphorylation through p38 MAPK pathway activation in casticin-induced cytocidal effects against the human promyelocytic cell line HL-60. Int J Oncol 43: 2046-2056, 2013.

5. Kikuchi H, Yuan B, Nishimura Y, Imai M, Furutani R, Kamoi S, Seno M, Fukushima S, Hazama S, Hirobe C, et al: Cytotoxicity of Vitex agnus-castus fruit extract and its major component, casticin, correlates with differentiation status in leukemia cell lines. Int J Oncol 43: 1976-1984, 2013.

6. Imai M, Kikuchi H, Yuan B, et al: Enhanced growth inhibitory effect of 5-fluorouracil in combination with Vitex agnus-castus fruits extract against a human colon adenocarcinoma cell line, COLO 201. J Chin Clin Med 6: 14-19, 2011.

7. Imai M, Yuan B, Kikuchi H, Saito M, Ohyama K, Hirobe C, Oshima T, Hosoya T, Morita $\mathrm{H}$ and Toyoda $\mathrm{H}$ : Growth inhibition of a human colon carcinoma cell, COLO 201, by a natural product,Vitex agnus-castus fruits extract, in vivo and in vitro. Adv Biol Chem 2: 20-28, 2012.

8. Yuan B, Imai M, Kikuchi H, et al: Cytocidal Effects of Polyphenolic Compounds, Alone or in Combination with, Anticancer Drugs Against Cancer Cells: Potential Future Application of the Combinatory Therapy. In: Apoptosis and Medicine. Ntuli T (ed). InTech, Croatia, pp155-174, 2012.

9. Ohno H, Miyoshi S, Araho D, et al: Efficient utilization of licorice root by alkaline extraction. In Vivo. Vol. 28. Brooklyn, pp785-794, 2014.

10. Sunaga K, Ohkawa K, Nakamura K, Ohkubo A, Harada S and Tsuda T: Mechanism-based inhibition of recombinant human cytochrome P450 3A4 by tomato juice extract. Biol Pharm Bull 35: 329-334, 2012.

11. Imai M, Kikuchi H, Denda T, Ohyama K, Hirobe C and Toyoda H: Cytotoxic effects of flavonoids against a human colon cancer derived cell line, COLO 201: A potential natural anti-cancer substance. Cancer Lett 276: 74-80, 2009.

12. Sugaya E, Jin W, Sugaya A, Sunaga K and Tsuda T: Inhibitory effects of peony root extract on the large conductance calcium-activated potassium current essential in production of bursting activity. J Herb Pharmacother 6: 65-77, 2006.

13. Sunaga K, Sugaya E, Kajiwara K, Tsuda T, Sugaya A and Kimura M: Molecular mechanism of preventive effect of peony root extract on neuron damage. J Herb Pharmacother 4: 9-20, 2004.

14. Demir F and Ozcan M: Chemical and technological properties of rose (Rosa canina L.) fruits grown wild in Turkey. J Food Eng 47: 333-336, 2001.

15. Ziegler SJ, Meier B and Sticher O: Fast and Selective Assay of l-Ascorbic Acid in Rose Hips by RP-HPLC Coupled with Electrochemical and/or Spectrophotometric Detection. Planta Med 52: 383-387, 1986.

16. Chrubasik C, Duke RK and Chrubasik S: The evidence for clinical efficacy of rose hip and seed: A systematic review. Phytother Res 20: 1-3, 2006.

17. Orhan N, Aslan M, Hosbas S and Deliorman Orhan D: Antidiabetic Effect and Antioxidant Potential of Rosa canina Fruits. Pharmacogn Mag 5: 309-315, 2009.

18. Gao X, Björk L, Trajkovski V and Uggla M: Evaluation of antioxidant activities of rosehip ethanol extracts in different test systems. J Sci Food Agric 80: 2021-2027, 2000.

19. Christensen LP: Galactolipids as potential health promoting compounds in vegetable foods. Recent Pat Food Nutr Agric 1: 50-58, 2009.

20. Deliorman Orhan D, Hartevioğlu A, Küpeli E and Yesilada E: In vivo anti-inflammatory and antinociceptive activity of the crude extract and fractions from Rosa canina L. fruits. J Ethnopharmacol 112: 394-400, 2007. 
21. Jäger AK, Petersen KN, Thomasen G and Christensen SB Isolation of linoleic and $\alpha$-linolenic acids as COX-1 and -2 inhibitors in rose hip. Phytother Res 22: 982-984, 2008.

22. Jäger AK, Eldeen IMS and van Staden J: COX-1 and -2 activity of rose hip. Phytother Res 21: 1251-1252, 2007.

23. Sadeghi H, Hosseinzadeh S, Akbartabar Touri M, Ghavamzadeh M, Jafari Barmak M, Sayahi M and Sadeghi H: Hepatoprotective effect of Rosa canina fruit extract against carbon tetrachloride induced hepatotoxicity in rat. Avicenna J Phytomed 6: 181-188, 2016.

24. Ninomiya K, Matsuda H, Kubo M, Morikawa T, Nishida N and Yoshikawa M: Potent anti-obese principle from Rosa canina: Structural requirements and mode of action of trans-tiliroside. Bioorg Med Chem Lett 17: 3059-3064, 2007.

25. Wu XW, Muzny DM, Lee CC and Caskey CT: Two independent mutational events in the loss of urate oxidase during hominoid evolution. J Mol Evol 34: 78-84, 1992.

26. Lombardi R, Pisano G and Fargion S: Role of serum uric acid and ferritin in the development and progression of NAFLD. Int J Mol Sci 17: 548, 2016.

27. Shekarriz B and Stoller ML: Uric acid nephrolithiasis: Current concepts and controversies. J Urol 168: 1307-1314, 2002.

28. Edwards NL: The role of hyperuricemia in vascular disorders. Curr Opin Rheumatol 21: 132-137, 2009.

29. Feig DI, Kang DH and Johnson RJ: Uric acid and cardiovascular risk. N Engl J Med 359: 1811-1821, 2008.

30. Nguyen MTT, Awale S, Tezuka Y, Shi L, Zaidi SF, Ueda JY, Tran QL, Murakami Y,Matsumoto K and KadotaS: Hypouricemic effects of acacetin and 4,5-o-dicaffeoylquinic acid methyl ester on serum uric acid levels in potassium oxonate-pretreated rats. Biol Pharm Bull 28: 2231-2234, 2005.

31. Zhao X, Zhu JX, Mo SF, Pan Y and Kong LD: Effects of cassia oil on serum and hepatic uric acid levels in oxonate-induced mice and xanthine dehydrogenase and xanthine oxidase activities in mouse liver. J Ethnopharmacol 103: 357-365, 2006.

32. Fridovich I: The Competitive Inhibition of Uricase by Oxonate and by Related Derivatives of s-Triazines. J Biol Chem 240 : 2491-2494, 1965

33. Ichida K, Matsuo H, Takada T, Nakayama A, Murakami K, Shimizu T, Yamanashi Y, Kasuga H, Nakashima $H$, Nakamura T, et al: Decreased extra-renal urate excretion is a common cause of hyperuricemia. Nat Commun 3: 764, 2012.

34. Michalets EL: Update: Clinically significant cytochrome P-450 drug interactions. Pharmacotherapy 18: 84-112, 1998.

35. Foster BC, Vandenhoek S, Hana J, Krantis A, Akhtar MH, Bryan M, Budzinski JW, Ramputh A and Arnason JT: In vitro inhibition of human cytochrome P450-mediated metabolism of marker substrates by natural products. Phytomedicine 10 334-342, 2003

36. Fujita T, Kawase A, Niwa T, Tomohiro N, Masuda M, Matsuda H and Iwaki M: Comparative evaluation of 12 immature citrus fruit extracts for the inhibition of cytochrome $\mathrm{P} 450$ isoform activities Biol Pharm Bull 31: 925-930, 2008.

37. Sand PG, Dreiseitel A, Stang M, Schreier P, Oehme A, Locher S and Hajak G: Cytochrome P450 $2 \mathrm{C} 19$ inhibitory activity of common berry constituents. Phytother Res 24: 304-307, 2010.
38. Kimura $\mathrm{Y}$, Ito $\mathrm{H}$ and Hatano T: Effects of mace and nutmeg on human cytochrome P450 3A4 and 2C9 activity. Biol Pharm Bull 33: 1977-1982, 2010

39. Kim H, Yoon YJ, Shon JH, Cha IJ, Shin JG and Liu KH Inhibitory effects of fruit juices on CYP3A activity. Drug Metab Dispos 34: 521-523, 2006.

40. Ishibuchi S, Morimoto H, Oe T, Ikebe T, Inoue H, Fukunari A, Kamezawa M, Yamada I and Naka Y: Synthesis and structure-activity relationships of 1-phenylpyrazoles as xanthine oxidase inhibitors. Bioorg Med Chem Lett 11: 879-882, 2001

41. Tian F, Li B, Ji B, Yang J, Zhang G, Chen Y and Luo Y: Antioxidant and antimicrobial activities of consecutive extracts from Galla chinensis:The polarity affects the bioactivities. Food Chem 113: 173-179, 2009.

42. Miraj S: Phytochemical composition and in vitro pharmacological activity of rose hip (Rosa canina L.). Pharmachem 8: 117-122, 2016.

43. Owen PL and Johns T: Xanthine oxidase inhibitory activity of northeastern North American plant remedies used for gout. J Ethnopharmacol 64: 149-160, 1999.

44. Umamaheswari M, AsokKumar K, Somasundaram A, Sivashanmugam T, Subhadradevi V and Ravi TK: Xanthine oxidase inhibitory activity of some Indian medical plants. J Ethnopharmacol 109: 547-551, 2007.

45. Nana FW, Hilou A, Millogo JF and Nacoulma OG: Phytochemical composition, antioxidant and xanthine oxidase inhibitory activities of Amaranthus cruentus L. and Amaranthus hybridus L. Extracts. Pharmaceuticals (Basel) 5: 613-628, 2012.

46. Ozyürek M, Bektaşoğlu B, Güçlü K and Apak R: Measurement of xanthine oxidase inhibition activity of phenolics and flavonoids with a modified cupric reducing antioxidant capacity (CUPRAC) method. Anal Chim Acta 636: 42-50, 2009.

47. Kılıçgün $\mathrm{H}$ and Altıner D: Correlation between antioxidant effect mechanisms and polyphenol content of Rosa canina. Pharmacogn Mag 6: 238-241, 2010.

48. Guengerich FP: Role of cytochrome P450 enzymes in drug-drug interactions. Adv Pharmacol 43: 7-35, 1997.

49. Christensen R, Bartels EM, Altman RD, Astrup A and Bliddal H: Does the hip powder of Rosa canina (rosehip) reduce pain in osteoarthritis patients? - a meta-analysis of randomized controlled trials. Osteoarthritis Cartilage 16: 965-972, 2008.

50. Rossnagel K, Roll S and Willich SN: The clinical effectiveness of rosehip powder in patients with osteoarthritis. A systematic review. MMW Fortschr Med 149: 51-56, 2007 (In German).

51. Cohen M: Rosehip - an evidence based herbal medicine for inflammation and arthritis. Aust Fam Physician 41: 495-498, 2012. 